Melvill, James Cosmo

Catalogue of the Hadfield collection of shells from

Lifu and Uvea

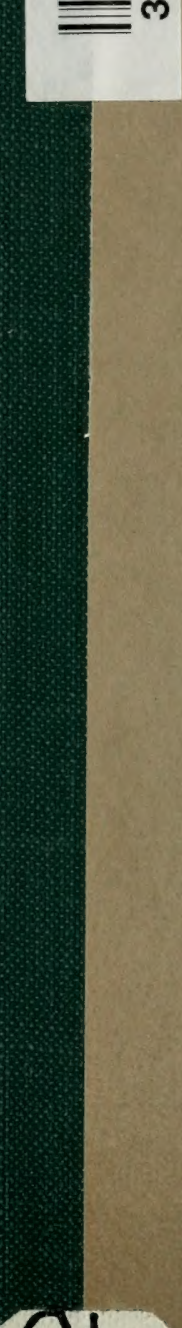

QL 406 $\mathrm{M}_{4}$ Dt. 1 



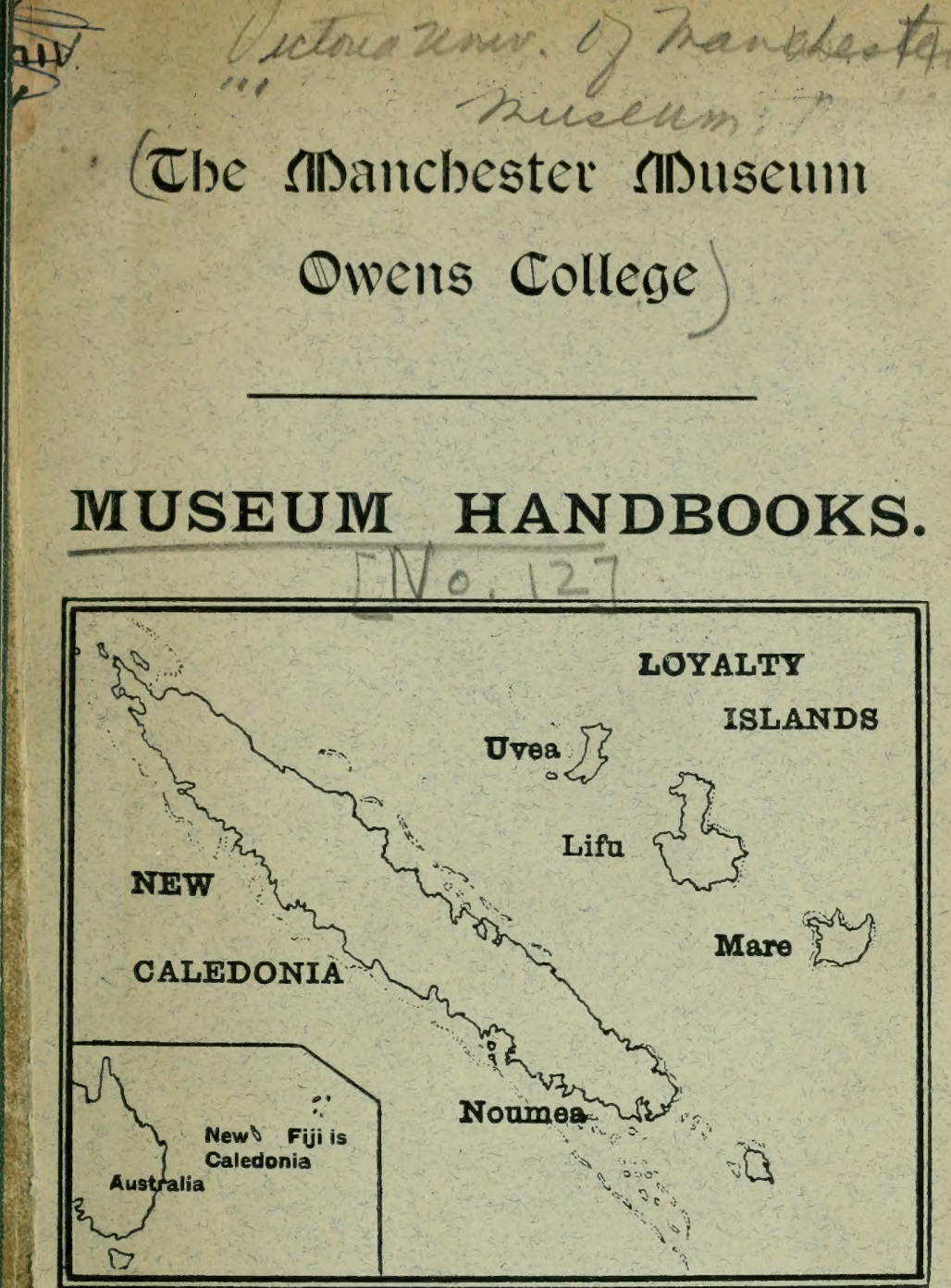

\section{IVIUSEUIV HANDBOOKS.}

\section{CATALOGUE}

$\mathrm{OF}$

\section{THE HADFIELD COLLECTION OF SHELLS}

FROM THE

LOYALTY ISLANDS.

Drice One sbilling. 

The Manchester museum, OWENS COLLEGE

MUSEUM HANDBOOKS

C A T A L O G U F OF

\section{THE HADFIELD COLLECTION \\ OF}

\section{SHELLS}

FROM

LIFU AND UVEA, LOYALTY ISLANDS.

BY

JAMES COSMO MELVII.L, M.A., F.L.S.,

AND

ROBERT STANDEN.
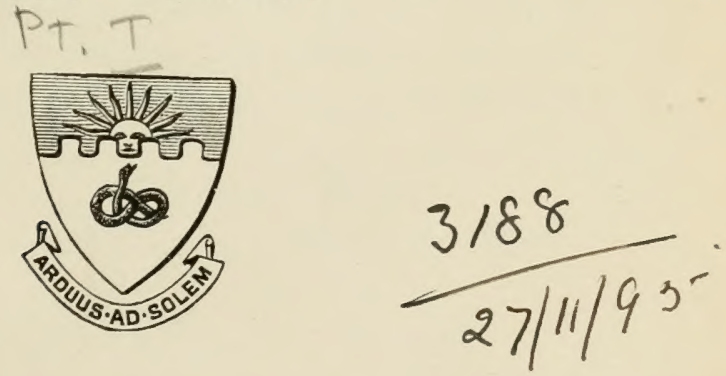

MANCHESTER : J. E. CORNISH.

I $\overline{895}$. 


$$
\begin{aligned}
& \text { Q2 } \\
& 406 \\
& m 4 \\
& P_{11} \\
& \hline 3188
\end{aligned}
$$




\section{INTRODUCTION.}

During the past few years large collections of the shells of Lifu and Uvea have been made by the Rev. James and Mrs. Hadfield, and have been consigned to several Manchester conchologists. By the kindness of Messrs. R. D. Darbishire, R. Cairns, and W. Moss, a very complete series of these shells has been presented to the Manchester Museum, which possesses in addition the types of the majority of the new species here described, though a few remain in Mr. Melvill's cabinet. They have been arranged for exhibition, and a list of them, with notes and descriptions of new species, was drawn up by Mr. J. Cosmo Melvill (a member of the Committee of the Manchester Museum) and Mr. R. Standen (of the Museum staff). As the collection is one of the largest and most important that has been received in this country from the Loyalty Islands, it has been thought desirable to afford the naturalists of Manchester and elsewhere an opportunity of obtaining separate copies of this catalogue, and it has therefore been reprinted from 'The Journal of Conchology' and issued as one of the Museum Handbooks.

William E. Hoyle,

Keeper of the Museum. 
NOTES ON A COLLECTION OF SHELLS FROM LIFU AND UVEA, LOYALTY ISLANDS, FORMED BY

THE REV. JAMES AND MRS. HADFIELD, WITH LIST OF SPECIES.

\author{
By JAMES COSMO MELVILL, M.A., F.L.S., AND \\ ROBERT STANDEN.
}

(Read before the Conchological Society, June 9th, r894).

THE Loyalty Islands, of which the three principal are Lifu, Maré, and Uvea, form part of the New Caledonian Archipelago, and are situate east of the main isle, with its capital Noumea, being placed long. $168^{\circ} \mathrm{E}$. lat. $22^{\circ} \mathrm{S}$. They are not, therefore, very far within the tropic of Capricorn.

Belonging to France, it is not surprising that several eminent naturalists of that nation have made an especial study of the fauna of this group. Accordingly we find, mainly in the pages of the 'Journal de Conchyliologie,' numerous papers on both the Terrestrial and Marine Mollusca, mostly from the pens of MM. Crosse, P. Fischer, Souverbie, Gassies, and three resident conchologists of note-Lambert, Marie, and Montrouzier. Mr. John Brazier* has likewise described a few new forms from this region, and we must not omit the name of Mr. Edgar L. Layard, C.M.G., for many years British Consul in New Caledonia, who here, as elsewhere, made large collections.

The period of most active research in this quarter, so far as the mollusca are concerned, would appear to have been the decade 1865-75, but several novelties have been described since that later date.

We cannot find, however, that any catalogue of the whole Marine Molluscan Fauna of the Loyalty Island group has been

Proc. Linn. Soc. N.S.W., iv. (1879), 1880, pp. 388-392. 
published, and, as a step towards this desired end, we venture to offer the following list of over 600 species, about twenty or twenty-one of which are considered new, this list being based upon a very beautiful and interesting collection, rich in individuals as well as number of species, formed by the Rev. James and Mrs. Hadfield, of Lifu, and coming mostly from that island, with some also from the neighbouring island of Uvea. They were collected during I89r-3.

Many of them, it is true, are beach shells, and a little worn, but their colours are so untarnished, and condition so perfect as to preclude their being considered as otherwise than in good condition. The small number of Pelecypoda is remarkable; the bulk of the shells collected are marine Gastropoda, and we may signalize Conus, Mitra, Cypræa, and Columbella especially as being very numerous, both in individuals and species. We have also included amongst these the terrestrial and fluviatile mollusca, collected by Mr. and Mrs. Hadfield.

It is nothing new to be able to pronounce these islands as being as rich, almost, in marine Mollusca as the famous Philippine Islands, or Mauritius, for MM. Crosse and Fischer give forty-five species of Mitra and fifty species of Conus, for instance, as being found within the New Caledonian region. Many of these are of very wide distribution, and it is curious to observe how large a number of the forms found in Mauritius are here also, some 3,000 miles or more to the eastward, although it forms part of the same vast sub-division, the Indo-Pacific Province. The late M. Paul Fischer, however, considers the Australo-Polynesian region, in which he places these islands, distinct from the Indo-Pacific Province of Woodward. These sub-divisions, however, must necessarily be somewhat arbitrary, and their lines of demarcation optional. The fact remains, that in the Marine Mollusca, at all events, there is a close connection between the Mauritian and the New Caledonian Fauna.

We had, at first, in mind the possibility of a general 
catalogue brought up to date of all the species hitherto reported from this group; but, upon reflection, we think it best merely to include those species received from time to time from $\mathrm{Mr}$. Hadfield. Our especial thanks are due to Mr. William Moss, Mr. R. Cairns, and Dr. G. W. Chaster. To Mr. Moss, for photographing for us some of the new species in a very clear and accurate manner, and for allowing us to inspect, on several occasions, the large stores he received from Mr. Hadfield. To Mr. Cairns for having aided Mr. Moss in the separation and arrangement of so large a mass of material and for having permitted the selection by us of what might be of interest for this catalogue; and to Dr. G.W. Chaster also for some beautiful photographs of the new species, reproduced herewith by the collotype process. This aid has been to us invaluable. To Mr. Edgar A. Smith, F.Z.S., of the Natural History Museum, South Kensington, and to Mr. Ernest Ruthven Sykes, F.Z.S., we must also offer our best acknowledgments, for their ready help in discriminating some of the more critical species, and advice on the subject of the new forms ; and to Mr. John Ray Hardy, of the Manchester Museum, Owens College, we are also indebted for much valuable assistance in the arrangement of the collection generally.

\section{LIST OF SPECIES.}

Class CEPHALOPODA.

ORdER DIBRANCHIATA.

FAMILY SPIRULIDAE.

Spirula Peroni Lam.- - Several specimens of this pelagic species, mostly in a fragmentary condition.

ORDER TETRABRANCHIATA.

FAMILY NAUTILIDE.

Nautilus macromphalus Reeve.-A long suite of individuals ranging in size from very young ones, 22 mill, in diameter, to adult. Two very fine specimens came in spirit and contained the animal in good condition. In 
the umbilical cavities of each of these specimens are colonies of a small Cirrhipede, allied to Lepas fascicularis $\mathrm{I}$.

N. pompilius Linné.-One adult specimen.

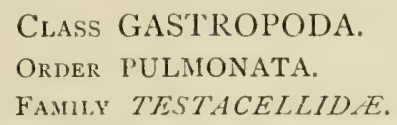

Micromphalia Saisseti Montr.-Several fine specimens. Rhytida inæqualis Pfr.-Several.

Diplomphalus lifuanus Montr.-Plentiful and very fine.

FAMILY HELICIDAE.

Helix aspersa Müller.-A large number of this species were received, mostly differing but slightly from European examples, but several are almost black in colour. Of course the species has been introduced, and Mr. E. L. Layard gives a graphic description of his first finding it in the Island of Lifu in 1879 , and subsequent tracing of the authors of its introduction, who were the officers of a French man-of-war (vide Wallis Kew, 'The Dispersal of Shells,' London, 1893).

H. (Geotrochus) sinistrorsa Deshayes=Buliminus sinistrorsus Pät. - A curious little shell, placed by Clessin in the sub-section Pseudopartula Pfr. Our specimens, of which there are a great number, have been identified as the above by Mr. E. L. Layard and others, but agree as nearly with Buliminus theobaldiamus Gassies, as figured in Gassies' Faune Conch. Nouvelle-Calédonie, pt. 2 pl. iii., fig. 9 .

H. (Patula) costulifera Pfr.--Several.

H. (Patula) confinis Gassies.-Several.

Bulimus (Placostylus) Alexander Crosse,-Several examples of this fine species.

B. (Placostylus) Edwardsianus Gassies._-Several.

B. (Placostylus) fibratus Martyn.-Several.

B. (Placostylus) insignis Petit.-Very abundant, most of the specimens minus epidermis. 
B. (Placostylus) ouveanus Dotzauer--Plentiful; from the island of Uvea.

FAMILY PUPIDA.

Buliminus (Rachis) Mageni Gass. $=$ B. histrio Pfr. -A large number of pretty examples in great variety of colour and pattern of markings.

Vertigo pediculus Shuttl,-Several specimens.

$$
\text { FAMILY STENOGYRID E. }
$$

Stenogyra (Opeas) artensis Gassies.-Common.

S. (Opeas) Souverbianus Gassies. - Exceedingly abundant in all stages of growth.

\section{FAMILY SUCCINEIDE.}

Succinea (Tapada) Montrouzieri Crosse $=$ S. australis Gassies, non Fér.-Fairly plentiful.

FAMILY AURICULIDAE.

Scarabus chalcostomus Adams.-Very abundant.

S. maurulus Gassies.-Many fine specimens.

Plecotrema Souverbiei Montrouzier.-One example.

P. labrella H. \& A. Adams.-Likewise one specimen.

Melampus luteus Quny.-A good many very fine specimens.

M. crassidens Gassies,-Several.

M. coffea Küst.--Not uncommon.

M. fasciatus Deshayes,-Common.

M. flavus Gmelin.-Several.

$$
\text { FAMILY LTMN/EID A: }
$$

Planorbis Montrouzieri Gassies.-Plentiful.

$$
\text { FAMILY PHYSIDAE. }
$$

Physa incisa Gassies.-Many fine specimens.

$$
\text { FANILY SIPHONARIIDF. }
$$

Siphonaria cochleariformis Reeve.-One specimen.

Siphonaria sp.-Several specimens ton worn to identify, but allied to $S$. diemenensis Quoy.

\section{ORDER OPISTHOBRANCHIATA.} FAMILY ACTEONID/E.

Actæon affinis A. Adams,--Several of this pretty species. 
A. (Buccinulus) solidulus linné.-Plentiful, and in great variety.

A. (Buccinulus) nitidulus I amarck.-Common.

A. (Buccinulus) alveolus Souverbie. - Several beautiful specimens.

FAMILY TORNATINIDAE.

Tornatina voluta Quoy.-Several specimens.

FAMIIY SCAPHANDRIDE.

Atys naucum Linné.-Two specimens.

A. debilis Pease--Several.

A. solida Linné,-Several.

\section{FAMILY BULLIDRE.}

Bulla ampulla Linné.-A considerable number of very small specimens.

B. nebulosa ('ould.-Many prettily-marked specimens.

Haminea tenera A. Adams.-Three specimens.

Haminea Cairnsiana sp. nov. (Pl. II., fig. r).

H. testi alba, pellucida, cylindrica, striis transwersim resularibus instructu, posticé truncatu, lateribus rectis, labro quadratulo, apud basim producto.

Long. sp. majoris; S-50 mill. Lat. 6 mill.

Hab. Lifu.

Several specimens, but only a few full grown. A very delicate white shell, allied to $I T$. paryrus and also $I I$. amligisur, both of $\Lambda$. Adams. It is cylindrical, transversely delicately striate, posteriorly truncate, sides straight, lip slightly quadrate, produced at the base. We received the specimens from $\mathrm{Mr}$. Robert Cairns, of Ashton-under-I,yne, just as Mr. Hadfield had forwarded them to him in shell-sand, and are glad of the opportunity of connecting his name with this new form, in slight recognition of the services he has rendered us.

\section{FAMILY RINGICULID E.}

Ringicula caledonica Morelet.--Several.

R. australis Hinds.-Many specimens, which we believe are referable to this species, but the genus is a difficult one, 
abounding in synonymy and false species, and badly need. ing a competent monographer.

\section{ORDER PROSOBRANCHIATA.}

FAMYY TEREBRIDA.

Terebra (Subula) casta Hinds.-Near T. hastata Menke. A pretty species. Several specimens.

T. (Subula) crenulata Linné.- Several fine specimens in various stages of growth.

T. (Subula) dimidiata Linné.-Several.

T. (Subula) duplicata Lamarck. - T'hree specimens.

T. (Subula) maculata Linné.-Very numerous in all stages of growth, several specimens being large and well marked.

T. (Subula) muscaria Linné. - Alsundant and very fine.

T. (Abretia) affinis Gray.-I beautiful, but common form. Numerous examples.

T. (Abretia) cerithina Lamarck, -One fult grown specimen in good condition.

T. (Hastula) circumcincta Ieshayes. - A concpicuous shell, spirally transverse-striated. Several specimens.

T. (Hastula) lanceata Iamarck, - I number of worn or fragmentary examples of this elegant species.

T. (Euterebra) Bernardi I) shases.-In Australian form. One or two specimens.

T. (Euterebra) circinata Deshayes. - A few cxamples. Originally described from China.

T. (Euterebra) Mariesii Sunith.--One specimen only; but exactly agreeing with the Japanese type; it has been referred to the describer of the species.

T. (Euterebra) straminea Gray. - 'Two specimens.

T. (Euterebra) tricolor sowerby. - Several imperfect but characteristic specimens.

T. (Myurella) argus Hinds.-One fine example only:

T. (Myurella) cingulifera Lamarck. - I few worn shells.

T. (Myurella) myuros Lamarck.-Uncommon. 
T. (Myurella) nectarea sp. nov. (Pl. II., fig. 2).

T. testa elongato-subulata, ad basim latiore, albida, parnm nitida, suprá suturas regulariter brunneo-maculata, anfractihus tridecim, transversim. multi-sulcatis, longitudinaliter costatis, costis gemmulatis infra, juxta suturas, duabusque macularum ordinibus plus minusze decoratis, ultimo anfractu bicingulato apud medium atque ad basim, apertura ouata, labro exteriore simplice.

Long:, 35 mill. Lat., ro mill.

Hab., Lifu.

One specimen of this distinct and handsome shell was brought home by Mr. Hadfield in IS9r-2. The longitudinal ribs beaded just below, and the double row of brown spots above the sutures, resemble no other species with which we are acquainted, excepting perhaps $T$. tigrina Gmelin, a smooth shell with the same disposition of marking; it bears also some superficial likeness to $T$. cormgata Lam., $T$. histrio Desh., and others of the same section. But in form $T$. interlineata I)esh., from the Sandwich Isles, gives the closest approach to our speries. This, we believe, is still unique in the Cumingian collection at South Kensington. In this shell, however, the whorls are divided by a broad transverse groove, and there is no sign of this in T. nectarea. Care must be taken not to confound imperfect specimens of Verlagus lFartinianus P'fr. with this shell.

T. (Myurella) nodularis Deshayes. - Not uncommon. Perhaps only a form of $T$. textitis Hinds.

T. (Myurella) oculata Iamarck. -Several good sperimens of this fine species.

T. (Myurella) subulata Linné.-Common.

T. (Myurella) textilis Hinds.-Common.

\section{FAMILY CONID E.}

Conus imperialis Linné.-Several; one very fine.

C. marmoreus Iinné-Numerous; mostly young specimens.

C. pulicarius Bruguière-Abundiant; several very fine specimens with epidermis intact. 
C. (Stephanoconus) baeticus Reeve - Very plentiful; mostly wave-worn.

C. (Stephanoconus) balteatus Sowerby.-i few small specimens.

C. (Stephanoconus) lividus Bruguière.-Mundant, but few in good condition.

C. (Stephanoconus) plumbeus Recre.-I few differing from the type in colour, which is brickdust red in the Lifu examples received.

C. (Puncticulis) arenatus Bruguiere.- (rreat numbers of small-sized specimens, some with epidermis quite perfect.

C. (Puncticulis) miliaris Bruguière.-Several.

C. (Puncticulis) nanus Broderip. Many small specimens.

C. (Coronaxis) fulgetrum Sowb. -- Three guod specimens.

C. (Coronaxis) hebraeus Linné.-Common.

C. (Coronaxis) minimus Linné.--Several.

C. (Coronaxis) musicus Bruguière-Common.

C. (Coronaxis) sponsalis Chemnitz.-Several.

C. (Coronaxis) vermiculatus Lamarck.-Several.

C. (Nubecula) geographus Limne--Many specimens in all stages of growth and fair condition, some large and wellmarked.

C. (Nubecula) striatus Iimé. - Numerous specimens in all stages, mostly worn.

C. (Nubecula) tulipa I immé. -Several small but pretty specimens, with a few of typical size.

C. (Dendroconus) figulinus Jimné. - Several very large specimens.

C. (Dendroconus) quercinus Bruguiire.--Three examples.

C. (Lithoconus) eburneus Bruguière. - Tery abuntant; small specimens of the form usually known as var. or sp. crassus Brug. occurring in hundreds.

C. (Lithoconus) litteratus Linné-Some small specimens, 
all var. millepunctata (Conus millepunctutus I amarck)-by some conchologists still considered a good species.

C. (Lithoconus) magus Linné.-One specimen only, in poor condition, of this ubiquitous Eastern species.

C. (Leptoconus) generalis Linné. - A few somewhat worn examples.

C. (Rhizoconus) cinctus Sowerby.

C. (Rhizoconus) lineatus Chemnitz.

C. (Rhizoconus) lithoglyphus Reeve=ermineus Dillw.

C. (Rhizoconus) miles Linné.

C. (Rhizoconus) planorbis Born.

C. (Rhizoconus) tahitensis Bruguière.

C. (Rhizoconus) vexillum Reeve. - A large number of each of the above species, of ordinary character and in poor or immature condition generally.

C. (Rhizoconus) sulphuratus Bruguière.--One good specimen. We think this is a species distinct from $C$. mustelimus Brug. with which it is usually joined.

C. (Chelyconus) catus Bruguière-Abundant.

C. (Chelyconus) monachus Linné--Several.

C. (Chelyconus) pertusus Bruguière. - One tine richlycoloured specimen.

C. (Cylinder) canonicus Bruguière. - l'wo specimens.

C. (Cylinder) textile Limné. Several rather poor examples.

C. (Hermes) atramentosus Reeve--Four specimens.

C. (Hermes) glans Bruguier. - Several good examples.

C. (Hermes) nussatella Linné.-A few small shells in poor condition.

C. (Hermes) tenuistriatus Sowerby.-One specimen only. Pleurotoma (Turris) abbreviata Reeve.-Very abundant and in fair condition.

P. (Turris) cingulifera L, amarck.--Several specimens somewhat worn.

P. (Surcula) bijubata Reeve.-Plentiful.

P. (Surcula) brevicaudata Reeve-Common. 
P. (Surcula) cincta Lamarck.-Common.

P. (Drillia) Hadfieldi sp. nov. (Plate III., fig. 23).

P. testa fusiformi, albida, rugosa, anfractibus seplem, longitudinaliter pancicostatis, costis crassiusculis, ventricosis, transversim funiculatis, costis alternatim squar rosé ochraceotinclis, apertura subrotunda, labro exteriore incrassato, intus denticulato, columellari simplice, extus minuté albipustulato.

Long., 6 mill. I.at., 3 mill.

Hab., Lifu.

A pretty species, small, roughly ventricosely costate, transversely crossed by coarse raised lines, the ribs being alternately squarely blotched with ochraceous, columellar lip smooth and simple.

P. (Drillia) Lamberti Montrouzier. -- Two specinens. Seemingly allied to the West Indian Plo zebra Lam.

P. (Drillia) obliquicostata Reeve-Common.

P. (Drillia) pupoidea A. Adams. - Very abundant. This species is identical with $P$ l. victor Sow., recently described from Mauritius.

P. (Drillia) regia lieck. I mumber of fine and beautifullymarked specimens. One of the most attractive of the genus.

P. (Crassispira) fuscescens (iray. - Several spucincms. Also found in the West Indies, thus showing a wide distribution.

P. (Clavus) bilineata Reeve-One or two examples.

P. (Clavus) unizonalis Lamarck.-Common.

P. (Clavus) vidua Reeve.-Plentiful; very variable in size.

Mangilia (Defrancia) albifuniculata Reeve.-()ne sperimen of a very small though striking species.

M. (Defrancia) granicostata Rece. - Sever.l pretty specimens.

M. (Defrancia) philippinensis Reeve.--Rather common.

M. (Defrancia) granularis E. A. Smith.-Two specimens. 
M. (Glyphostoma) Aliciæ sp. nov. (PI. II., fig. I5). M. testa elongato-fusiformi, gracillima, nivea, anfractibus decem, in medio ventricosulis, apud suturas subconstrictis, undique confertim transverso-striatis, longitudinaliter rotundocostatis, apertura oblonga, laliro exteriore multum incrassato, brunneo-tincto, precipue marginem apud suturalem, simul ac ad busim labri exterioris.

Long. 9 mill. Lat. 4-50 mill.

Hab. Lifu.

About twenty specimens of this pretty species of Glyphostoma, which occupies a position near G. corssilabrum Reeve, but is distinct. It is white, graceful, ten-whorled, the whorls somewhat ventricose, transversely striate, and roundly longitudinally costate. The outer lip is much thickened. and the outer sinus stained brown, there being also a brown blotch towards the base of the outer lip. We have much pleasure in associating with this species the name of Miss Alicia Mayor Standen, who has assisted us considerably in the general assortment of a large portion of the collection.

M. (Glyphostoma) calcicincta sp. nov. (PI. III., fig. 21). M. testa minuta, incrassatu, migosa, pellucida, nivea, anfractibus sex, longitudinaliter crassicostatis, costis paucis prominentiluss, apudmediun transwersim una conspicua zona, calcarea, candida, opaca, circumambiente, ultimum apud anfractum latiore, apertura angusta, labro exteriore crassiusculo, albo, minuté pustulato, intus quadri-denticulato, columellari quadri-plicato.

Lons, 4 mill. Lat. 2-25 mill.

Hab., Lifu.

A single specimen in beautiful condition of a little bright white semi-opaque shell, this opacity being caused by a deadwhite transverse band crossing the coarse ribs and becoming broader in the last whorl. The outer lip, under a lens, is very beautiful, being minutely warted, and with four denticles, the columellar margin with four plaits. This species is of the same character as G. rugosa Mighels.

M. (Glyphostoma) crassilabrum Reeve. - One or two specimens. 
M. (Glyphostoma) cremonilla sp. nov. (Pl. III., fig. 31). M. testa fusiformi, solidiuscula, pallide-straminea, infrô suturas ochraceo-cincta, anfractibus septem, apud medium longitudinaliter ventricosé crassi-costatis, transversim undiliratis, liris paucis, incrassatis, apertura oblonga, labro exteriore intus sex-denticulato columellari multi-plicato.

Long., sp. maj., I 2 mill. Lat., 6 mill.

Hab., Lifu, in shell sand.

By those authors who would reconstitute the genus or subgrcnus bursonic (Bellardi), founded upon a Tertiary fossil pussessing one or more columellar plaits, this species and two or three others from Lifu would be included in it. At present we prefer following the arrangement as set forth in our National Collection, and adaing these new forms to the sub-genus Glyphostoma, and taking as the types $G$. crassilalinm Reeve and $G_{i}$. ruscosum Mighels. The G. cremonilla cannot be confounded with $G$. misrocinctum (Montrouzier) from New Caledonia; it is a coarscrribled species, and banded with pale ochre, not black. 'Two specimens.

M. (Glyphostoma) Emmæ sp). nov. (I'l. III., fig. 2.4).

M. testa acuminata, fusiformi, semi-pellucida, pallidé straminea, ventricosa, anfractibus octo, omnibus preter ultimum longitudinaliter paucicostatis, transzersim fortiter supra suturas bi vel tri-funiculocinctis, regulariter inter costas longitudinalcs, juxtu suturas, squarrosé brunnco-maculatis, ultimo anfractu apud medium simili modo decorato, longitudinaliter multi-costulato, transversimque multi-funiculato, apertura oblonga, labro exteriore denticulato, presertim uno dente conspicuo columellari quadri-denticulato, canali brevi.

Long., I 2 mill. Lat., 5 mill.

$H a b$., Lifu, in shell-sand.

A very elegant little species, in good condition, somewhat ventricose, acuminate, semi-transparent, and straw-coloured, unicolorous excepting for the few square brown spots situate just above the sutures, between the longitudinal costec on the central whorls and continued in the middle of the last whorl, culminating in the specimen before us in a large dorsal square brown mark near the outer lip. The whorls, with the exception 
of the last, are few ribbed, and transversely crossed twice or thrice with strong projecting corded ribs, the last whorl is many ridged and many corded. Mouth oblong, with a very strong prominent tooth in the outer lip, which is, besides, f-denticulate, the columellar margin being also 4-denticulate. Canal rather short.

We have much pleasure in associating the name of Mrs. Emma Hadfield with this attractive little shell.

M. (Glyphostoma) Giliberti Souverbie.---1)escribed originally from the island of Lifu: our only specimen agrees fairly with the description and representation.

M. (Glyphostoma) rugosa Mighels.-Several.

M. (Glyphostoma) scalarina Deshayes.-One specimen.

M. (Glyphostoma?) theskela sp. nov. (Pl. III., fig. 26). M. testa attenuato-fusiformi, gracillima, delicatula, albida, anfractibus sex vel septem, longitudinaliter costulatis, transversim densiliratis, liris tenuibus, supra, juxta suturas, inter costas et apud medium anfractus ultimi brunneo-maculatis, apertura oblonga, labro exteriore crassiusculo, simplice, margine columellari octo-plicato.

Long., 7-50 mill. Lat., 3 mill.

Hab., Lifu.

This very interesting little shell we place provisionally under Glyphostoma, from which assemblage it differs in the simple outer lip and more uniform shape. The inner or columellar margin of the lip possesses seven or eight close and minute plicæ, there is also one minute process at the parietal sinus. It is of a graceful attenuate form, six-whorled, or perhaps seven, but the apex is broken off in the only specimen we have. The pure whiteness of the shell is relieved by a row of brown spots between the ribs just above the sutures and in the middle of the last whorl. The specific name is from the Greek $\theta^{\prime}(T \kappa \epsilon$ dos 'wonderful,' in allusion to the strange configuration of the species.

M. (Cythara) cithara (iould. $-\Lambda$ few pretty specimens.

M. (Cythara) inepta Smith.-One fine specinen. Hitherto 
only recorded from Honduras! The author of the species has examined our specimen and agrees with our determination.

M. (Cythara) reticulata Reeve - Common; a very clegant form.

M. (Cythara) vexillum Reeve - Abundant.

M. (Daphnella) bella Reeve.-Sereral specimens of this curiously-marked species.

M. (Daphnella) dulcinea sp. nov: (I'l. III., fig. 25.)

11. testa fusiformi, albida, anfractibus sex, vintricosis, apud suturas impressis, longitudinaliter costulatis, transacrsin delicatuli-striatis, hic illic minutissimé sparsim brunneopunctatis, apertura oblonga, labro exteriore effuso.

Longr, 6 mill. Lat., 2-50 mill.

Hab., Lifu.

A very delicately-striated shell, with siwollen whorls, impressed at the sutures, obscurely longitudinally ribbed; outer lip effuse, under a lens the surface is seen to be very finely besprinkled with minute dust-like brown spots. One specimen.

M. (Daphnella) nexa Reeve-A few only.

M. (Daphnella) saturata Reeve.-Several.

Besides these there are a few species of minute Plemrotomide that we cannot yet determine. Many species have been described, mainly by French conchologists, of which we have no representatives in our National or other collections.

FAMILY CANCELLARIIDAR.

Cancellaria (Trigonostoma) costifera huwerly,---Sucural specimens. This genus seems but poorly represented in the Loyalty Islands, although several are described from New Caledonia.

\section{FAMILY OLIVIDAE}

Oliva (Strephona) episcopalis I anarck. - I large nunlet of handsome specimens.

O. (Strephona) erythrostoma Lamarck.--Viry numerous. Some specimens unusually large, all in excellent condition and brilliantly coloured. 
O. (Strephona) masaris Duclos. $-\mathrm{A}$ fine specimen, now in the collection of the Ven. Archdeacon Anson.

O. (Strephona) guttata Lamarck.-A large number of very pretty specimens in all stages.

O. (Strephona) maura Lamarck.-Two specimens only:

O. (Strephona) picta Reeve.--Two specimens, in worn condition.

O. (Strephona) tremulina Lamarck. - Several very fine specimens of an unusually dark form.

O. (Porphyria) sericea Bolt.-Two fine specimens.

Olivella parvula Martyn(?) - Several specimens, all somewhat worn, and therefore rather doubtful.

\section{FANILY HARPIDAE.}

Harpa articularis Lamarck. - One specimen in young condition.

H. minor Rumphius.- Two specinens in the Manchester Museum, Owens College, and three fine ones in the collection of the Ven. Archdeacon Anson-all received from Mr. Hadfield.

FAMILY MARGINELLIDAE.

Marginella (Persicula) lifuana Crosse. A cunsiderable number of this pretty little sjecies.

M. (Volvaria) caledonica Jousseaume. - Very near the West Indian $M$. avena and $M$. teniata, but the columella is only three-plaited, and the angle at the suture of the last whorl is more pronounced. Several specimens.

\section{FAMILY MITRID E.}

Species of this family, exclusive of Turicula, are exceedingly well represented by an enormous number of individuals in all stages, and for the most part in fairly good condition.

Mitra (Eumitra) cardinalis Gmelin.-Several.

M. (Eumitra) episcopalis Linné.-.Many very fine specimens, some of the adults having the outer lip beautifully serrated. 
M. (Eumitra) pontificalis I amarck,-One adult and sereral young specimens.

M. (Scabricula) eximia A. Adams. - All of a beautiful wam reddish orange colour variety. One of the most abundant shells sent. The typical form occurs in the Mauritius.

M. (Scabricula) sphærulata Martyn.-I'ery common, but mostly worn and poor.

M. (Scabricula) texturata Lamarck, var. lifouana Crosse. -Very plentiful.

M. (Cancilla) filaris Linné. - This species, for many years known as M. filosa Born., possesses two well marked varieties, the typical $\boldsymbol{M}$. filaris being an attenuate and fusiform shell, the form $\beta$. nexilis Martyn, to which all the Lifu and Uvea specimens we have seen belong, is much more obese than the type. The late Mr. Andrew Garrett, who is entitled to speak authorititively on the subject, as his personal acquaintance with the Polynesian Mitride was more extended and full than that of any who have preceded or followed him, considered $M$. nexilis a true species. (c.f. Garrett, Polynesian Mitride, "Journal of Conchology," vol. iii., P. 2 I, I 880).

M. (Chrysame) ambigua Swainson.-Plentiful.

M. (Chrysame) coronata Chemnitz.-This species and $M$. tiarella seem almost too closely allied. The forms we here place under $M$. coronata would appear intermediate between the two. It is abundant on the coasts of Lifu and Uvea.

M. (Chrysame) ericea Pease.

M. (Chrysame) laeta Adams.

M. (Chrysame) lugubris Swainson.

M. (Chrysame) tiarella Swainson.

M. (Chrysame) ticaonica Reeve.

M. (Chrysame) turgida Reeve.

M. (Chrysame) vexillum Reeve.

Most of the above very plentiful, but usually waterworn and in poor condition. 
M. (Chrysame) fulvosulcata Melvill, Journal of Conchology vol. v., p. 287, I888. (Pl. III., fig. 32.)

Originally described from Mauritian specimens sent by Mr. Robillard to Mr. G. B. Sowerby. Several have now come to our notice from Lifu, and the species will doubtless occur in intermediate localities. The transwerse furrows, stained with yellow, impart at once a characteristic appearance to the species. We figure the original type, from Mauritius.

M. (Volutomitra) honesta sp. nov. (Pl. III., fig. I 7.)

M. testa pyramidato-fusiformi, nitida, brumea, crassiuscula, levi, anfractibus sex, ultimo rapidé accrescente, ventricoso, apud medium transversim unicingulatis, apertura oblongra, intus cinerea, labro exteriore paullum incrassato, effuso, collumella triplicata, plicis conspicuis, cinereis.

Long., Io mill. Lat., 45 mill.

Hab., Lifu.

Two specimens of a little Mitra somewhat resembling the Mediterranean Tolutemitric clenus I am., and possibly a tropical form of that variable species, though its presence in Lifu would hardly be suspected.

M. (Strigatella) decurtata Recve - M. scutulata I am.-Several very fine specimens.

M. (Strigatella) flexilabris Swainson._-One or two in gond condition.

M. (Strigatella) litterata Lamk. - M. maculosa Recre.Common.

M. (Strigatella) retusa Reeve $=$ M. paupercula I amarck. -A large number of rather poor specimens.

M. (Strigatella) zebra Reeve-Common.

M. (Turricula) turriger Reeve--One specimen.

M. (Costellaria) arenosa Lamarck.-Common.

M. (Costellaria) armiger Reeve.-Several.

M. (Costellaria) cadaverosa Reeve.-Common.

M. (Costellaria) Deshayesi Recve.-Some large and very beautiful specimens of this interesting species. 
M. (Costellaria) dimidiata Sowb. - A few good specimens.

M. (Costellaria) discoloria Chemnitz.-Common.

M. (Costellaria) exasperata Reeve - Abundant, but mostly of a variety we characterize as follows:-

M. (Costellaria) exasperata var. Hadfieldi var. nov. (Pl. II., fig. I 4.)

Shell turreted, eight or nine ribbed, differing from the type in being dark-brown, banded at the line of the sutures of the upper whorls, and also twice transversely banded at the last whorl. Occasionally specimens occur wholly suffused with dark-brown.

An extremely common form at the Loyalty Islands, several hundred specimens having been forwarded by Mr. Iadficld. M. (Costellaria) modesta Reeve.-A few.

M. (Costellaria?) nitidissima sp. now. (Pl. III., fig. 10.)

11. testa minuta, perlevi, nitente, brunnea, tenui, anfractitus sex, paullum ventricosis, lonsitudinaliter costulutis, apertura oblonga, labro exteriore vix incrassato, columella quadriplicatu.

Long., 5 mill. Lat., I'5 mill.

Hab., Isifu.

Four specimens from shell-sand, all precisely alike, of a very small brown, very shining and smooth shell, longitudinally roundly costate; columella four-plaited. The species may really belong to Volutomitra rather than Costellaria.

M. (Costellaria) nodilyrata A. Alams. - Sevural.

M. (Costellaria) pacifica I mmarck. - Rather larger than M. cadaverosa of which it may be but a variety. Many specimens.

M. (Costellaria) semifasciata I amarck. Not uncommon.

M. (Pusia) alveolus Reeve.-Three not quite full grown specimens we refer almost certainly to this species; the vivid black and white marking, as in M.tusa Recve, rendering it conspicuous. It is allied both to this species and also M. Shoplandi Melvill, lately described from Aden.

M. (Pusia) amabilis Reeve.-A few good specimens. 
M. (Pusia) dermestina Lam.--Several.

M. (Pusia) lubens Reeve.-One specimen.

M. (Pusia) luculenta Reeve-Several specimens. Prolsably a variety of $M$. Graeffei Crosse.

M. (Pusia) muriculata Lamarck.-Extremely abundant, but few specimens in good condition.

M. (Pusia) nodosa Swainson. - Several.

M. (Pusia) Savignyi Payr. - T'wo specimens. Qute inseparable from the Mediterranean shell (fide E. A. Smith).

M. (Pusia) rosea Reeve. - A pretty purple species. T'wo or three specimens.

M. (Pusia) tuberosa Reeve--Very common.

M. (Pusia) tusa Reeve. - Several pretty specimens in good condition.

M. (Pusia) venustula Reeve-Common.

M. (Cyllithea) casta A. Adams.-One good specimen of this elegant species.

M. (Cylinder) dactylus Limné. - One very fine specimen.

M. (Cylinder) nucea Gronovius.-Common.

M. (Cylinder) crenulata Lamarck. $-A$ few small specimens. Imbricara conica Schmck.-Many small specimens.

1. olivæformis Swainson.-Several.

I. ossea Reeve - I. punctata swainson. - A number of rather worn specimens.

FAMIIY FASCIOLARTIDA.

Fusus gradatus Reeve.-One good specimen.

Fasciolaria filamentosa Nartyn. - A number of very fine fresh specimens.

Latirus lautus Reeve.-Several.

L. nodatus Martyn.-One young specimen.

L. (Plicatella) caledonicus l'etit. - Very plentiful, but mostly in poor condition.

L. (Plicatella) polygonus Iinné.-Two specimens in the Manchester Museum, one in the collection of the Ven. Archdeacon Anson. 
L. (Peristernia) aureotinctus I.amarck. - One specimen in the Manchester Museum, one in J. C. Melvill's collection.

L. (Peristernia) chlorostomus Sowerby $=$ L. crenulatus Kiener.-Tluree nice specimens.

L. (Peristernia) incarnatus I)enayes.-.Several specimens in various stages.

L. (Peristernia) nassatulus Iamarck.-Several.

\section{FAMIIY TURBINELLIDRE.}

Cynodonta ceramica Kiener.-Two small specimens.

C. cornigera Lamarck.--Several immature specimens.

C. imperialis Reeve $=$ C. tubifera Anth.-Two sperimens.

$$
\text { FAMIIIY BUCCINIDAE. }
$$

Tritonidea (Cantharus) gracilis Reeve.

T. (Cantharus) undosus Linné.

T. (Cantharus) marmoratus Reeve.
A few specimens of each, mostly worn.

T. (Cantharus) menkeanus Inuker.-()ur only example agrees very well with Japanese specimens of Dunker's species in J. C. Melvill's collection.

Engina alveolata Kiener.-One or two examples.

E. astricta Reere. - Several sood sperimens showing some variation.

E. iodosia Duclos. (Pl. III., fig. 20). - A most interesting rediscovery of a lost species, which has not been with absolute certainty identified by any conchologist since the time of the original describer, although its identity was suspected by the late Mr. G. W. Tryon, Junr. It appears to run into its allies, E. monilifera Reeve, and $E$. cchinata Pse. (both of which will have to be merged in indosiog) and exactly resembles I nclos' figure. 'These fisures are considered by some to be fantastic and artificial, so many - exceeding fifty species - having been thus described by Duclos, and not identified since, mostly appertaining to the genera Columbella, Engina and Oliza; but 
we hope, since several have been satisfactorily re-identified, others will follow. His plates, reproduced also by Tryon, are very clear, and should leave little room for doubt when comparison is needed.

\section{E. lineata Reeve.-In hundreds.}

E. mundula sp. nov. (PI. II., fig. 6).

E. testa parza, oblonga, solida, alba, obtusa, anfractibus sex, longitudinaliter costatis, cos:is sulcis transversim decussatis, gemmulato-noduliferis, brunneo ochreoque alternatim pictis, apertura angusta, labro crassiusculo, brunneo hic illic maculato.

Long., 8 mill. Lat., 4 mill.

$H a b$., Lifu.

A few specimens of a pretty little shell, doubtless allied to $E$. lauta Reeve from the Philippines, but differing much in size, (being about half the diameter of E. lauta), and also in greater obesity of whorl.

E. phasinola Duclos.-Several specimens. There can be but little doubt that this species is not a Columbella.

E. rutila Reeve.-Very rare.

E. spica sp. nov. (Pl. II., fig. I 2).

E. testa attenuato-pyramidata, solida, allida, squarrosé brunneo maculato, anfractibus octo, undique transversim densi-striatulis, irregulariter costatis, costis subacutis, ultimo anfractu in medio conspicué angulato, apud basim attenuato, apertura aususta, labro exteriore incrassato, intus denticulato.

Long., i I mill. Lat., 5 mill.

Hab., Lifu.

A striking little shell, of which only one specimen in very fine condition occurred. Its nearest allies are $E$. alveolata Kiener, and E. Reevei Tryon=alveolata Recve non Kiener. It is white, solid, attenuate at both extremities, with irregular acutely noduled ribs, the nodules imparting a prickly angular appearance to the centre of the last whorl especially. The mouth is narrow, dentate on the interior of the outer lip, which is thickened in the manner characteristic of the genus; the 
coloration is, as has been said, white, with squarrose brown variegated markings.

E. sinensis Melvill._Proc. Malac. Soc, vol. i., p. 227,1895 . (Pl. III., fig. 27).

This species, described since the original reading of this paper, from two specimens in the National Collection marked 'China Seas,' has, curiously enough, turned up in fair quantity, viz., ten or twelve specimens, in the Loyalty Islands also. IVe have thought it worth while to append a figure taken from Lifu specimen.

E. variabilis Pease.-A few, but worn, specimens.

E. zatricium Melvill._Proc. Malac. Soc., vol. i., p. 5 I, 1894. (Pl. II., fig. 4).

Described from Mr. Hadfield's first consignment of specimens, and found not to be infrequent by the numerous examples, since received. It is allied to E. bonasia von Mart. and E. fusiformis Pease, but distinct from both. We give a representation of this species.

E. zonata Reeve.-In remarkable abundance, and more plentiful than E. lineatu, which, while it occurred in its hundreds, was eclipsed by the thousands of $E$. zonata. Mostly in capital condition, and showing a good deal of variation, some specimens, for example, being quite black at the base, with hardly any white markings at all.

E. (Pusiostoma) mendicaria Linné. - Abundant and variable.

It will be seen by the above array of species of this genus that the Loyalty Islands may almost be considered their metropolis, and we hope, in future, for other interesting and perhaps yet unknown species from this locality. It is urgently to be wished that some specimens might be dredged alive so as to afford opportunity for examination of the radula.

Phos nodicostatus E. Ad.-Two specimens of this elegant form. 
P. senticosus Linné.-Common and very fine.

\section{FAMILY NASSIDAE.}

Nassa arcularia Linné.

N. coronata Bruguière.

N. callospira A. Adams $=N$. callosa A. Adams.

N. (Niotha) albescens Dunker.

N. (Niotha) densigranata A. Ad.-Not quite typical.

N. (Arcularia) globosa Quoy.

N. (Arcularia) granifera Kiener.

N. (Alectryon) glans Linné.

N. (Alectryon) monilis Kiener.

N. (Alectryon) mucronata A. Ad.

N. (Alectryon) papillosa Linné.

N. (Alectryon) suturalis Sowerby.

N. (Telasco) dispar Adams=N. filosa Gray.

N. (Telasco) fluctuosa Adams.

N. (Telasco) gaudiosa Sowerby, - Many varietics of this species.

N. (Hebra) uricata Quoy and Gaim.

N. (Hima) eximia H. Adams.

N. (Hima) plebecula Gould.

Of the above, $N$. granifera and $N$. monilis are the most abundant-some hundreds of each; but nearly all are well represented by good specimens in various stages of growth. Besides these, there are seven or eight other Nassce that we have been unable, so far, to identify.

\section{FAMILY COLUMBELLIDAE.}

Columbella (Pygmæa) Tankervillei Montr. - Abundant, but poor specimens.

C. (Pygmæa) turturina Lamarck.-Plentiful; variable in size and colour.

C. (Pygmæa) Tyleri Gray=C. pardalina Lam.-Over a thousand specimens in every conceivable variation of colour and marking, and in excellent condition. 
C. (Pygmæa) varians Sowerby, $-\Lambda$ large number of pretty specimens.

C. (Pygmæa) versicolor Sowerby.-Several.

C. (Mitrella) albina Kiener.-Common.

C. (Mitrella) ligula Duclos. - Very abundant, and showing considerable variation in colouration. Quite the most beautiful of the genus, in our opinion.

C. (Atilia) galaxias Reeve.-Several pretty examples.

C. (Amycla) conspersa Gaskoin. - An elegant species of which we have a few nice specimens. We are indebted to Mr. S. Pace for these last two identifications.

C. (Anachis) lachryma Gaskoin.-Very few.

C. (Anachis) marquesa Gaskoin. - Several specimens, which exhibit so much variation, both in form, sculpture, and marking, as to be apparently separable into two or three species. We are again indebted to Mr. Pace, who is making an especial study of the genus, for his opinion on this matter.

\section{FAMIY MIURICIDAE.}

Murex (Chicoreus) adustus Iam. - Serural good specimens and many worn ones. This includes $M$. australiensis A. Adams, a colour variety represented in some quantity.

M. (Vitularia) vitulinus $\mathrm{I}$.am. = M. purpura Chem.Three specimens.

M. (Ocinebra) benedictus sp. nov. (Pl. II., fig. I2).

M. testa parva, candida, orato-fusiformi, anfractibus sex bian "ulatis, undique transatersim temuissime. sub lente, strigillatis, longitudinaliter pancicostatis, costis angulatim arguté anguliferis, hic illic squarrose pallide brunneo tessellatis, apertura angusta, oblonga, ad basim froducta, latherexterione conspicué denticulato.

Long., 7 mill. Lat., 4 mill.

Hah., Lifu, in shell-sand.

A very small but exquisite shell, of which we have only seen one full-grown specimen. It is white, microscopically transversely finely lirate, longitudinally few ribbed, ribs sharply 
angled and almost prickly. The aperture is narrowly oblong, outer lip conspicuously toothed within. It is a moot question whether this species is an Ocinclura or Corallioplitar; we incline to the former view at present.

M. (Ocinebra) breviculus Sowerby.-One specimen.

Purpura persica Lamarck.-Five fine specimens.

P. (Thalessa) bitubercularis Lamarck. $-\Lambda$ few small specimens.

P. (Thalessa) hippocastanum Linné.-One specimen.

P. (Thalessa) intermedia Kiener.-Several.

P. (Stramonita) rustica Lamarck.-One specimen.

P. (Stramonita) vexillum Reeve.-A few small examples.

P. (lopas) sertum Lamarck.-One fine specimen.

Pentadactylus (Ricinula) arachnoides Lamarck $=\mathrm{P}$. ricinus L.-Several specimens of both type and var, albolabris Blainville.

P. (Ricinula) biconicus Blainville.

P. (Ricinula) clathratus Lamarck.

P. (Ricinula) digitatus Lamarck.

P. (Ricinula) horridus Lamarck.

P. (Ricinula) spectrum Reeve.

A fair number of each of above, excepting $P$. biconicus, in moderate condition.

P. (Sistrum) anaxares Duclos.-Several examples of this pretty little Engina-like species.

P. (Sistrum) asper Lamarck.-Common.

P. (Sistrum) cavernosus Reeve $=$ P. ochrostomus Blainville.-Common.

P. (Sistrum) chaideus Duclos--Common.

P. (Sistrum) chrysostomus Desh.-Common and variable.

P. (Sistrum) fragrum Blainville.-One example only.

P. (Sistrum) margariticolus Broderip.-Several specimens. A variable species that requires more careful attention in order to discriminate its extent of variation.

P. (Sistrum) morus Lamarck.-Abundant. 


\section{FAMILY CORALLIOPHILIDAE.}

Coralliophila coronata Barclay.-Worn, but agreeing with specimens of the Mauritian shell in J. C. Melvill's collection.

C. madreporarum Sowerby.-Several specimens in a worn condition.

C. monodonta Quoy.-One specimen.

C. neritoidea Chemnitz $=$ C. violacea Auct. - Sereral fine specimens in the Manchester Museum and the collection of the Ven. Archdeacon Anson.

\section{FAMILY TRITONIDAE}

Triton variegatus Lamarck.-Many, in various stages of growth.

T. (Simpulum) aquatilis Reeve-One good specimen.

T. (Simpulum) chlorostomus Lamarck.- One only.

T. (Simpulum) eximius Reeve-One.

T. (Simpulum) gemmatus Reeve- Several. A very neat shell.

T. (Simpulum) pilearis Linné.-Three examples.

T. (Simpulum) rubecula Linné...- J'entiful and extrencly varied in colouration. A rather small form.

T. (Cabestana) labiosus Wood.-One example.

T. (Lotorium) pyrum Linné.-A single fine specimen.

T. (Lotorium) tuberosus I amk.-Many small specimens.

T. (Epidromus) decapitatus Reeve.

T. (Epidromus) obscurus Reeve.

T. (Epidromus) truncatus Hinds.

A single specimen each of the above three species.

T. (Persona) ridens Reeve. - One very juvenile example only.

R. (Lampas) affinis Broderip.-Several.

R. (Lampas) livida Sowerby,-Abundant.

R. (Lampas) siphonata Reeve.-One specimen.

R. (Apollon) anceps Lamarck.--One worn example.

R. (Apollon) pusilla Broderip.-Several, worn.

FAMILY CASSIDIDAE.

Cassis (Semicassis) pila Reeve.-One poor example. 
C. (Casmaria) torquata Reeve.--Three specimens in grood condition.

C. (Casmaria) vibex Linné.-Several.

\section{Family DOLIIDAE.}

Dolium olearium Brug.--Several medium-sized examples.

D. perdix Linné.-Several; one or two very fine.

\section{FAMIIY CYPRAEIDAE.}

Ovula ovum Linné-A large series of very fine shells, one of which has been bored for wearing as an ornament.

O. tortilis Martyn.-One only, a very beautiful specimen in fine condition.

O. (Calpurnus) verrucosa Linné.-Many fine examples of this pretty species.

Cypræa argus Linné.-Many very beautiful specimens, some of large size and with great variety of pattern.

C. carneola Linné.-Common; variable in size, some being exceptionally large.

C. caurica Linné--Abundant, but very few specimens in good condition.

C. coffea Gray.-A striking little shell, occurring in considerable numbers.

C. exanthema Linné.-Several, young and adult, of ordinary character.

C. interrupta Gray.-Several, most of them badly worn.

C. isabella Linné.-Abundant.

C. mauritiana Linné.-A great number. Some of the adult shells are very fine. Many specimens are young, in all stages.

C. microdon Gray.-Abundant.

C. Rashleighana Melvill (Pl. II., figs. 7 and 8). $-\mathrm{A}$ few specimens of a shell hitherto unique, and considered of uncertain locality. The establishment of the particular habitat of this species is of considerable interest. We 
have thought it worth while re-figuring as the former representations were hardly up to the mark.

C. scurra Chemnitz.--Several, rather worn. One good specimen in Archdeacon Anson's collection, and another, very fine, in that of Mr. Cairns.

C. tabescens Solander. - Several specimens, showing considerable variation; some are very dwarfed in form, and two are of a pale straw colour without the usual dorsal marking.

C. talpa Linné. - Rather common; several specimens unusually brilliant in colour and large-sized.

C. testudinaria Linné.-Several very fresh and beautiful specimens.

C. ursellus Gmelin.-Common and very fine.

C. (Aricia) arabica Linné--Plentiful in all stages.

C. (Aricia) annulus Linné. - Common; some unusually bright in colour.

C. (Aricia) caput-serpentis Lamarck-Common; scveral very large specimens.

C. (Aricia) moneta Linné.-Abundant and variable in size and form.

C. (Aricia) sulcidentata (iray.-One young lut func live specimen with teeth not fully developed in Mr. Cairns' collection.

C. (Luponia) asellus Linné.-Plentiful.

C. (Luponia) aurora Solander $=$ C. aurantium Mirt. Mr. Hadfield, in a letter to one of the authors, records coming across a fine specimen of this slecll in a mative hut, where it was held in much vencration by the occupant, who considered it a kind of fetish.

C. (Luponia) cernica Sowerby.-Several.

C. (Luponia) clandestina Iinné. Tye alsent, but the pretty little var. Artuffili Jousseaume (Pl. III., figs. 2S, 29) is abundant. 
C. (Luponia) cribraria Linné.-Plentiful.

C. (Luponia) erosa Linné--Plentiful.

C. (Luponia) flaveola Linné.-Several.

C. (Luponia) gangrenosa Dillwyn.-A few.

C. (Luponia) helvola Linné.-Common.

C. (Luponia) lutea Gronow.-A fine series; many, however, being somewhat waterworn, in which condition they might readily be mistaken for $C$. ziczac. Some of our specimens seem to be var. Humplireysii Gray.

C. (Luponia) Iynx Linné-_Moderately plentiful, but most'y worn.

C. (Luponia) mappa Linné.-A number of remarkably fine examples in the most perfect condition, including a handsome specimen of var. panerythra Melv. (in Mr. R. Cairns' collection), and several of var. subsignata Melv.

C. (Luponia) poraria Linné.-Very abundant, some remarkably fine and richly coloured.

C. (Luponia) poraria var, albinella nov.-Base white; dorsal surface yellow with white ocelli, the purple tinge of the type entirely wanting. A very beautiful and striking colour variety. Two specimens.

C. (Luponia) spurca Linné.- $\Lambda$ few rather small specimens.

C. (Luponia) stercus-muscarum Lamarck.-Several. A form nearly allied to C. punctata L.

C. (Luponia) tigris Linné.--Many large and beautiful shells. Also some in a juvenile condition.

C. (Luponia) vitellus Linné.---Cummon. Mostly small in size. Two examples of var. sarcodes Melv.

C. (Luponia) ziczac Gmelin.-Several.

Trivia Childreni Gray.-One fine specimen.

T. insecta Mighels._-Several; variable in size.

T. oryza Lamarck. - Several.

T. staphylæa Linné.-Common.

T. (Pustularia) nucleus Linne.-Abundant. 
T. (Epona) cicercula Linné. - Common; mostly worn. Several examples of var. Lienardi Jousseaume.

T. (Epona) globulus Linné.-Common.

Erato corrugata Hinds.-Several.

FAMILY STROMBIDAE.

Strombus thersites Gray $=\mathrm{S}$. ponderosus Phil.-One specimen of this rare species in the finest condition, brought over by the Rev. James Hadfield on his first visit in $89 \mathrm{I}-2$ (now in J. C. Melvill's collection).

S. urceus Linné.-Received by J. C. Melvill from Mr. Hadfield's first consignment, I89r. It does not occur in the second or third collections, which is surprising.

S. (Monodactylus) pacificus swainson $=\mathrm{S}$. novæzealandiæ Chem.- Two fine specimens and several worn ones.

S. (Canarium) floridus Lamarck. - Some hundreds of specimens, showing great variation in size and colouration.

S. (Canarium) gibberulus Linné.-Abundant.

S. (Canarium) samar Chemmitz.-One fine specimen.

S. (Conomurex) luhuanus Linné.-Several small specinens.

Pterocera (Harpago) chiragra Linné. - Several specimens, chiefly of a stunted form and richly coloured.

P. (Heptadactylus) lambis Linné.-One small specimen in the Manchester Museum, and a few mature in that of the Ven. Archdeacon Anson, of Birch Rectory, Rusholme.

Terebellum subulatum Linné-Some hundreds of fine specimens with great variety of marking. The size and beauty of these surpass those we have seen from any other quarter of the tropics.

\section{FAMILY CERITHIIDAE.}

Triforis connatus Montrouzier.-One of the larger species.

T. Hindsii Deshayes.-Several.

T. sculptus Hinds.--Several.

T. violaceus Quoy.-Of a pale lilac hue, whorls much noduled. 
Cerithium armatum Phil. var. lifuensis nov. (P'. III.. fig. 33): Differs from the type in greater nodulosity of whorls, especially round the sutures, and in more pronounced yet delicate marking and brighter colour. Apparently common in Lifu.

C. carbonarium Phil. - Three or four specimens. Allied to the West Indian $C$. atratum Born.

C. corallinum Sowerby.-One small specimen of this Philippine Island species, received through Mr. R. Cairns.

C. columna Sowerby.-An immense number of specimens, many being fine and thousands in fragmentary condition.

C. dichroum sp. nov. (Pl. II., fig. 5).

C. testa solida, breviter fusiformi, pallidé ochracea, transversim crassistriata, anfractibus. ncto, irregulariter suprá suturas nodulosis atque castaneo zonatis, ultimo apud peripheriam alterâ zonâ, nunc tenui, nunc latiore et interdum intermpter succincto, canali paullum producto, apertura ovata, labro simplice.

Long., 8 mill. Lat., $3{ }^{\circ} 50$ mill.

$H a b$., Lifu.

A somewhat shortly fusiform species, the whorls much cemented together, and since they are uniformly transversely striate, it is difficult to descry the sutural juncture. A brown chestnut band, in some specimens broader than in others, encircles the shell just above the sutures, the last whorl also having an additional band round the periphery. Various nodules, somewhat irregularly placed, also encircle the whorls above the sutures.

Several specimens. Near C. unilineatum Pease, from the Galapagos Islands.

C. dubium Sow. = C. eludens Bayle.-Several in a young state.

C. gracile Pease $=$ C. rostratum Sow.-Several.

C. morus Lam. $=$ C. variegatum Quoy. - Not so abundant as some of the other tropical forms at Lifu. Mostly young specimens. 
C. nassoides Sow $=$ C. maculosum Mighels. - A few specimens of this pretty little species.

C. salebrosum Sow. - Several, showing much beautiful variation.

C. zebrum Kiener.-Described originally from the Galapagos Isles, but we see hardly any difference in the numerous Lifu specimens, including the var. delcitum Sowb, which is also represented.

C. (Vertagus) aluco Linné-A handsome and infrequent species.

C. (Vertagus) articulatum Ads. \& Reeve.-Several.

C. (Vertagus) fasciatum brugrière. - I large number of very fine specimens. One good and several poor examples of the form known as $V$. martinianus $\mathrm{Pfr}$.

C. (Vertagus) lineatum I amarck. - Several specimens.

C. (Vertagus) obeliscus Bruguière--Several specimens in poor condition.

C. (Vertagus) semi-nudum Sowb.--Several. i form allied to $C$. obeliscus and differing slightly in sculpture.

C. (Lampania) lacteum Kiener.-Plentiful.

C. (Lampania) piperitum Sowerby-Plentiful.

C. (Lampania) zonale Bruguière--Several.

C. (Pyrazus) palustre 1,im..-Two specimens in poor condition.

Bittium sp.--Several specimens of a form near 13. almuptum Watson. Probably a new species, but we hesitate at present to describe it as it does not seem to possess many salient characters.

Potamides caledonicus Jousse.-One small specimen only. Cerithiopsis sinon Bayle. (PI. I., fig. 3).-Several specimens of a remarkably beautiful shell, which appears to be so scarce and little known that we give a figure of it. It was originally described as C. clathratus Ads., and in the British Museum there are three tablets so named; but Bayle preferred the change on account of this name being pre-occupied by a fossil species. 
FAMILY MODULIDAE.

Modulus tectum Gmelin.-Several. A small variety.

FAMILY PLANAXIDAE.

Planaxis virgatus Smith.-Common.

FAMILY VERIIETIDA.

Vermetus (Phylacodes) if. nodoso-rugosus lischke.Very few specimens, enabling us only to make a guess at the identification. Lischke's species, however, seems the nearest to our form.

FAMILY TURRITELLIDAE.

Mathilda sinensis Fischer. (Pl. III., fig. 27.)-One specimen in J. C. Melvill's collection, received from Mr. Hadfield in 1891 . White and umbilicate, very exquisite in sculpture, but only 6 mills. in length.

FAMUY MELANTIDEE.

Melania Matheroni Gassies.-Abundant.

M. Rossiteri Gassies, - One or two in Mr. Cairns' collection.

FAMILY LITTORINIDEE.

Littorina obesa Sowerby,-Common.

L. (Melaraphe) mauritiana I am.--Several specimens ; a small form.

L. (Melaraphe) undulata Gray.-Several.

Tectarius miliaris Quoy.-Several.

FAMILY SOLARIIDAE.

Solarium (Philippia) oxytropis A. Adams.-Several, but small. A rare species.

Torinia infundibuliformis Gmelin. - Sereral, prettily chequered.

T. perspectivunculum Chemnitz.-Two specimens.

FAMILY LITIOPIDAE.

Diala A. Adams is included as a sub-genus of Litiofa by Tryon and also Paul Fischer, but we are inclined to agree with 
Adams as to the generic distinctness of both this and Alaba, also of Arthur Adams.

Three species or perhaps more of this genus appear to occur, but so much difficulty attends the elucidation of the species, and so little is their distribution known, that it is impossible to arrive at any certainty on the subject. The genus, distinct in our opinion from Litiopa, as observed above, sadly needs a competent monographer.

D. Hardyi sp. nov. (Pl. II., fig. 10).

D. testa pyramidato-fusiformi, lacta, solida, nitida, anfractibus septem, apud suturas canaliculatis, undique regsulariter striato-sulcatis, ultimo apud peripheriam ansulato, apirhura rotunda labro apud marginem columellarem ochraceo. Long., 3.25 mill. Lat., I'15 mill.

A small milk-white species, very regularly striately sulcate, unicolorous and without markings.

D. Hardyi $\beta$ prolongata var. nov. (Pl. II., fig. II).

Whorls 8, more rounded, shell more elongate, not angled at the periphery.

Long., 4 mill. Lat., I’I 5 mill.

Hab., Lifu and Uvea, with the preceding, in shell sand.

These two forms occur together, and are distinct enough when taken notice of at first, but the more one studies them, the more they are seen to be joined by intermediates. The variety seems near $D$. suturalis Adams from the Philippine Isles. We have much pleasure in connecting with this species the name of Mr. John Ray Hardy, of the Manchester Museum, Owens College, who has rendered us much assistance in the sorting and investigation of this Lifu collection of shells.

D. ludens sp. nov. (Pl. II., fig. 9).

D. testa oblonga fusiformi, solida, albescenti, anfractious sex planatis, levibus, in medio circáque liasin ultimi anfractus sulcato-striatis, transzersim albo tessellatis, precipué juxta suturas, et apud peripheriam, transversimque intermptis lineis brunneis decoratis. Apertura rotunda, labro crassiusculo simplice.

Long., 4 mill. Lat., I’75 mill.

Hab., Uvea (in shell-sand, from Mr. Hadfield). 
Seven or eight specimens, but only one or two in good condition. Allied, though not very nearly, to D. lauta Adams, from South Australia, but much smaller and less shining. The compressions at the sutures are not so marked, and the lineation of the brown transverse marking more interrupted and not so broad. The opaque white tessellated ornamentation is not present in lauta. D. albugo Boog Watson, from Wednesday Island ('Challenger' Expedition) of which there are specimens also in J. C. Melvill's collection from Thursday Island, from shell-sand collected there lyy Mr. Arnold Umfreville Henn, is also allied, though distinct.

D. semistriata Phil.= varia A. Ad.-Rare, and agreeing with authentic specimens from Adams marked 'varia' in J. C. Melvill's collection.

FAMILY RISSOIIDAE.

Rissoina distans Anton. = R. canaliculata Schwartz.Two specimens.

R. minuta Neville.-One specimen, like $R$. scolopax or $R$. sulconcinna, but only $0^{\prime} 3$ millimetres in length, may perhaps be placed here. (It is figured in Kuster's Conch. Cab., pl. xv., fig. I 2).

R. scolopax Souverbie.-Many, Evidently common, and very beautiful.

R. (Zebina) curta Adams.-Several.

R. (Zebina) funiculata Souverbie. - Several. Perhaps identical with $R$. spiralis Souverbie, of which we have not seen specimens.

R. (Zebina) subconcinna Souverbie.-Several. Resembling R. scolopax Souv.

R. (Moerchiella) spirata Sowb. - Two specimens of the type, and several of

var. Lamberti Souverbie, var. Orbignyi A. Adams, and var. artensis Montrouzier.-This last a turreted form. 
R. (Moerchiella) spira! is Souverbie. - One specimen seems to approach $R$. artensis Montrouzier, just mentioned.

R. (Pyramidelloides) miranda Adams.-Several. Probably synonymous with $R$. insolita Desh. from the Mauritius. A curiously sculptured and very beautiful species.

\section{Barleeia Chasteri sp. nov. (Pl. III., fig. 22).}

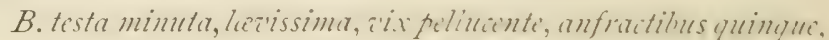
lavibus, ventricosulis, ochraceo-brunneis, infra suturas transversim vitta calarea succinctis, simul ae apud basin anfractus ultimi, apertura rotunda, pupinceformi, labro fere continuo, incrassato.

Long., I'75 mill. Lat., I mill.

Hab., Lifu (in shell-sand).

Twenty to thirty specimens of this pretty little shell have come under our obsersation. Some specimens are of a darker ochreous-brown colour, and therefore show the contrast with the chalky white transverse band just below the sufures more distinctly than the paler forms. The whorls are five in number, and the whole shell is extremely smooth, barely translucent; whorls slightly ventricose; operculum unknown.

We think (as pointed out to us by Mr. Edgar Smith) that the genus Barlicit fits this species more nearly than any of the other Rissoid sectional gencta or sulf-genera, although we believe the seas of furope alone contain nine-tenths, if not all, the hitherto described species of the gents. M. Fischer includes Fairbankia hemlutuna l3lanford, howerer, with Jiarlecia, and it is probable that it is enenerally diffused orer the tropical area-indeed, in Pactel's Catalogue, some Mauritian and ('alifornian species, not known to us, are included likewise.

FAMILY CYCLOSTOMATIDAE.

Omphalotropis granum $\mathrm{Pfr}$-Common.

FAMILY TRUNCATELLIDAE.

Truncatella conspicua Brown - T. vitiana (ild..-Not uncommon. 


\section{FAMILY HIPPONYCID E.}

Hipponyx antiquatus Linné $=H$. mitrula Gmel.-Many, mostly waterworn.

H. australis Linné.-Not uncommon; one example in situ on a specimen of Turbo petholatus.

H. barbata Sowerby.-Several.

FAMILY CAPULIDA.

Capulus intortus Meusch.--Several.

C. militaris Linné.-Several.

Calyptræa hipponiciformis Reeve.-Several, mostly worn.

C. tortrix Reeve.-Several pretty specimens.

FAMILY NATICID $A E$.

Natica chinensis Isam.-Common, and in good condition.

N. Gaidei Souverbie $=\mathbf{N}$. lineozona Jouss._Plentiful. A very clearly marked and beautiful little shell.

N. Gualteriana Phil._An imperfect specimen or two.

N. marochiensis Gmelin.-Nany specimens of this widelydistributed species, showing some amount of variation.

N. picta Recluz. - Worn, but with the characteristic markings.

N. Robillardi Sowerby.-Allied to $N$. gamlice Recluz, and hitherto only known from Mauritius. Several fine specimens. We are indebted to Messrs. Edgar A. Smith and E. R. Sykes for aid in determination of this species.

N. violacea Sowerby.-Common.

N. (Ruma) simiæ Chemnitz.-Common.

N. (Ruma) succinoides Reeve $=$ N. melanostoma ('mel. -Abundant.

N. (Mamma) aurantia Iam.-Several ; the finest hitherto recorded, in the collections of John Hardy and R. Cairns.

N. (Mamma) mamilla Linné-Common.

N. (Mamma) orientalis Gmelin.-Common.

\section{FAMILY SCALARIIDAE.}

Scalaria (Scala) pyramidalis Sowerby.-One specimen. 
S. (Amaea) fimbriata Adams (?)-One pretty specimen, which we somewhat doubtfully place here, has been referred to Mr. E. A. Smith, who informs us that it is near to Adams' species, which is unfigured and was described from Japan, but it has fewer ribs, and may be new. We refrain, however, from naming our solitary example until more specimens come to hand for comparison, especially as it is not in first-rate condition.

S. (Acrilla) gracilis H. Adams.-Two specimens.

\section{FAMILY EULIMID AE:}

Eulima proxima Sowerby.--Two specimens.

\section{FAMILY PIRAMIDELLIDAE.}

Pyramidella mitralis A. Adams.--Several.

P. nitida A. Adams - - Common.

P. nodicincta A. Adams.--Several.

P. variegata A. Adams.-Abundant.

Obeliscus dolabratus A. Adams.-Several.

O. pulchellus A. Adams.-Several.

O. sulcatus $A$. Adams.

O. turritus A. Adams.-Several.

Odostomia interstriata souverbic. - Two sperimens-one white, one yellowish - the number of whorls is not quite as many as in the typical form, of which there are specimens from Upolu in J. C. Melvill's cabinets, but we place the species here with considerable certainty.

Syrnola brunnea A. Ad.-Three worn specimens of this interesting form.

S. Mossiana sp. nov. (P1. II., fig. I6).

S. testa attemuatu, lavi, nitida, delicatula, anfractihus septem, suprá subrentricosis, apud suturas pallidé ochracco-cinctis, ultimo anfractu recto, prolongato, in medio ochracco-cincto, apice obtuso, aperturâ obloner $\hat{a}$, labro exteriore simplice, columella uniplicata.

Long., 7.50 mill. Lat., $2 \cdot 25$ mill.

Hab., Lifu. 
A few specimens only. The shell is smooth, whitish, shining, pyramidal, whorls seven, the upper ones somewhat ventricose, the last whorl straight and produced, with a palc ochraceous median band, this band being also perceptible around the sutures of the upper whorls. The apex is obtuse, outer lip simple, columella with one fold or plait. We have much pleasure in associating with this shell the name of Mr. William Moss, of Ashton-under-Lyne.

\section{FAMILY HELICINIDRE.}

Helicina gallina Gassies. - A pretty species. Fairly common. H. lifouana Crosse. - In great numbers, and very variable. Specimens from Uvea which have been identified as a form of this species, are considerably larger than those received from Lifu.

H. mediana Gassies.-Common and variable.

H. Primeana Gassies. -Common. Several specimens of the carinated variety.

H. sphæroidea Pfr.-Common.

H. sublævigata Pfr.-Common.

Several thousands of the above-mentioned small species of Helicina came to hand; in one or two parcels received from Mr. Hadfield they had apparently been used for parking, the interstices between the larger shells being filled in solid with them. Many of the shells are "dead," and very few retain the operculum.

\section{FAMILY HYDROCENIDAE.}

Hydrocena Fischeriana Gassies.-Abundant.

\section{FAMILY NERITIDA:}

Nerita polita Linné.-Several.

N. (Peloronta) aurantia Recluz, - Several.

N. (Peloronta) chrysostoma Recluz.-Common.

N. (Peloronta) filosa Reeve.-Several.

N. (Peloronta) plicata Linné.-Several.

N: (Thelicostyla) albicilla Linné.-Several. 
Nerita (Thelicostyla) marmorata Homb.-Common.

Neritina (Vitta) morosa Gassies.-Common.

N. (Dostia) lifuensis Ads. \& Angas.--Several.

N. (Clithon) nucleola Morelet.-Common.

FAMILY NERITOPSID FE.

Neritopsis radula Linné.-One fine specimen.

$$
\text { FAMILY TURBINIDAE. }
$$

Turbo petholatus Linné.-A number of very fine and perfect specimens; also many young ones.

T. (Senectus) argyrostomus Iinné--One remarkably fine specimen.

T. (Senectus) artensis Montrouzier.-Two fine specimens in the collection of the Ven. Archdeacon Anson. Peculiar to the New Caledonian group.

T. (Senectus) chrysostomus Linné-Several pretty specimens.

T.(Senectus) moluccensis Phil.--One of the most interesting examples in the collection. Although we have never seen the type, the description given ly lhilippi is so lucid, and Sowerby's figure (Thes. Conch., Turbo, pl. xiv., fig. I 77) so plain that we have had but little difficulty in our identification. The original locality is Amboyna. The shell is a warm yellow, narrowly umbilicate, with polished transverse ribs, the interstices being olscurely crenulate, whorls five in number, and the ribs flecked with red and yellow spotting ; last whorl slightly angled lelow the sutures, and outer lip tinged with green. In the Manchester Museum collection.

T. (Senectus) nicobaricus Gmelin.-Al)undant.

T. (Senectus) radiatus (imelin,-Many, mostly young or worn.

T. (Senectus) sparverius Gmelin.-Several.

T. (Senectus) spinosus Chemnitz.-One fine specimen.

FAMILY TROCHIDE.

Trochus niloticus Linné.-One small specimen. 
Polydonta conspersa Raff.-Several.

P. histrio Reeve--Several.

P. tricatenata Reeve.-'Two specimens.

P. tubifera Kiener.-Several.

P. obesa Reeve.-Several.

P. (Infundibulum) concava (imelin.--Two, in the collection of the Ven. Archdeacon Anson, of Birch Rectory, Rusholme, both received from Mr. Hadfield, in 1892.

Pachypoma rhodostoma Lamarck.--Several.

Pyramidea fenestrata Gmelin.-Several.

P. obeliscus Gmelin = P. pyramis Born. - Three specimens.

Minolia glaphyrella sp. nov. (Pl. III., fig. I 8).

M. testa rotundo-conica, profundé sed angusté umbilicatu, solidiuscula, pallidé straminea, apice obtuso, anfraitibus quinque, ventricosis, ad suturas impressis, undique transversim arcté livicinctis, liris regularibus microscopicé brunneopunctatis, continuis, anfractu ultimo apud peripheriam subangulato, obscusé brunneo-maculato, apertura parva, rotunda, labro exteriore vix incrassato, simplicé, margine columellari parum contracto.

Long., 2*25 mill. Lat., 5 mill.

Hab., Lifu.

A neat little species, very pale straw colour, rather solid, and uniformly delicately transversely lirate; under a lens some very obscure small brown spotted markings on the lirx, and larger spots at the periphery, are observable; umbilicus deep but narrow, mouth small, roundish. This shell seems for the present, at all events, best located in Minolia (A. Ad.), where we would also place MI. le fouctna rather than in Monilea (Swains.). It is more elaborately sculptured than $M$. lifouana, to which it does not bear more than a passing resemblance.

Minolia lifouana Fischer.-A few of this pretty little shell.

Clanculus clanguloides Wood. - A pretty pink-suffused variety.

C. Thomasi Crosse. - One, not perfect, but exhibiting the peculiar sculpture. 
C. unedo A. Adams.-Several.

Elenchus (Thalotia) elongatus Wood.-Sivial.

G. nucleus Phil.--Common. Not quite typical, but not sufficiently distinct to separate in any way.

Ethalia guamensis Quoy.-Five specimens. The absence of any species of Umbonium seems remarkable.

Margarita striatula P'hil.-.-Several specimens which, if not this species, are a close ally. We are indebted to Mr. E. Ruthren Sykes for the identification.

\section{FAMILY DELPHINULID. IE.}

Delphinula distorta Linné.-One specimen.

D. laciniata Lamarck. - Two very handsome specimens.

Liotia varicosa Phil.-One or two specimens.

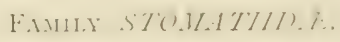

Stomatella haliotidea sowerby: Two sper inchs.

S. maculata Quoy \& Gaim.-One specimen.

S. Mariei Crosice. 'Two, agrecing cxactly with authentic specimens in J. C. Melvill's collection.

S. orbiculata A. Adams.-Several.

S. papyracea Chemnitz.-Several.

S. sulcifera Lamarck.-One small example.

Gena stellata Souverbie.-One fine specimen.

Stomatia decussata $\lambda$. Adams,-One specimen.

\section{FANILY H.1LIOTII).T:}

Haliotis sp.:- In the collection of the Ven. Archdeacon Anson. Too imperfect to identify.

H. (Padollus) ovina ('hemnitz... Several small specimens.

$$
\text { FAMILY ACAIEIDATE. }
$$

Acmæa crucis Ten.-Woods,-One pretty specimen.

A. conoidea Quoy.- Several.

$$
\text { FAMLY PATELLIDAT. }
$$

Patella stellaris Reeve.-Several.

P. variegata Reeve.-Several. 


\section{Class SCAPHOPODA.}

FAMILY DENTALIID AE.

Dentalium sp.--Three specimens too worn to identify with certainty, but closely allied to $D$. politum L.

\section{Class PElecypoda. \\ Order teTrabranchiata. \\ FAMILY OSTREIDR.}

Ostrea crista-galli Iinné. - One perfect specimen and several valves of juvenile examples.

FAMILY SPONDYLID E.

Spondylus ocellatus Reeve.-Several valves.

S. pacificus Reere. - This last we identify with some little doubt, the specimens being in rather poor condition.

FAMILY PECTINID E.

Pecten pallium Iinné.-One perfect specimen and several valves of this beautiful species.

P. radula Linné.--Valves only, mostly juvenile.

FAMILY AVICULID AE.

Avicula (Meleagrina) margaritifera I.inné. - 1 number of small-sized specimens.

A. (Meleagrina) anomoides Recre. Two specimens, one perfect but very juvenile.

Crenatula $\%$. flammea I amarck. One young example.

Perna if. linguæformis Reeve. - One young sperimen.

FAMILY $M Y T I I, I D A E$.

Mytilus ap.-Several specimenis perhaps of M. suldistortus Recluz, but too young to identify with certainty.

Septifer pilosus Rerluz.-.Seviral perfect specimens.

Modiola tulipa I amarck. - We cannot make out any differ. ence between our specimens and the Australian and West Indian forms of this species.

Lithodomus gracilis Phil. Two very fine and perfert examples, 
FAMILY ARCIDE.

Barbatia fusca Brug.-Four perfect specimens and several valves.

Two or three other species of Arcide are in the collection, but all single valves, and somewhat worn. One comes near A. japonica Reeve.

Pectunculus c.f. novo-caledoniensis Angas.--One large valve and three jurenile examples which seem to be this species.

\section{FAMILY CARDTTIDAE.}

Mytilicardia muricata Sow.-Many single valves.

M. variegata Brug.-Several valves.

FAMILY ERYCINIDAE.

Kellia fidelium sp. nov. (PI. III., fig. 30).

$K$. testa ovato-rotunda, tenui, nitida, lactea, latere postico rotundato, antico compressiusculo, vix subquadrato.

Long., i 7 mill. Lat., I3.5 mill.

Hab., Lifu.

A very beautiful milk-white shining species, not unlike some of the Sintille in form, but more agreeing with the genus Kellia, to which we have relegated it. The hinge appears that of a normal Kellia. Rare.

\section{FAMILY TRIDACNIDAE.}

Tridacna crocea I.amarck. - Two perfert specimens, one of them a juvenile only 20 mills. wide.

$$
\text { FAMILY CARDIIDAE. }
$$

Lævicardium australe Sowerby.-Several.

Hemicardium cardissa Limné.-One small sperimen.

H. hemicardium Linnś.--Several valves.

H. (Fragum) unedo Linné.-Valves only.

FAMILY CHAMIIDA.

Chama foliacea Quoy.-Worn valves only, but showing the distinctive red staining within.

$$
\text { FAMILY CYPRINIDAE. }
$$

Libitina angulata Lam.- Several very pretty specimens. 


\section{FANHY VENERTDR:}

Caryatis inflata Sow. $=$ C. affinis Gmel, Several ralves. Lioconcha castrensis Linné. Several well-marked specimens in various stages of growth.

L. picta Lam.--Two fine specimens.

L. sulcatina Lam.-Valves only.

Chione sp., near C. cancellata Chem.-One small example.

C. costellifera Ads. \& Reeve-Several perfect specimens, almost identical with Philippine examples of this species.

C. marica Linné.-Several beautiful specimens.

C. reticulata Linné.-One very fine specimen and some single valves.

\section{FAMILY DONACID,E:}

Donax (Latona) australis Lam. - One good perfect example and several single valves.

\section{FAMIL PSAMMOBIIDA:}

Asaphis deflorata Linné.-Many fine specimens.

\section{FAMIII LUCINIDA:}

Lucina (Codakia) exasperata Reeve. - Two jerfect specimens and several valves.

L. (Codakia) fibula Reeve. Many in great variety of color and form, white, salmon-pink, and yellow.

L. (Codakia) interrupta Lam. - One fine perfect specimen received by J. C. Melvill from Mr. Hadfield in ISgr; also one in the Anson collection from the same source.

L. (Codakia) punctata I.inné. One perfect and sereral valves.

Loripes edentulus Linné. Many imperfect specimens; valves only:

Corbis fimbriata I.inné. - Several larese and very beatiful specimens.

$$
\text { FAMILY TELLINID/E. }
$$

Tellina (Tellinella) interrupta Wood. (Ine specimen.

T. (Tellinella) jubar Hanley $=T$. virgata var.-Two beautiful specimens. 
T. (Tellinella) perna Speng.-One or two.

T. (Tellinella) picta Desh.--Several fine examples.

T. (Tellinella) rugosa Born.-Some good specimens, and several single valves.

T. (Tellinella) virgata I inné-Common.

T. (Tellinella) vulsella Chemn.-Valves only.

T. (Donacilla) rhomboides Quoy it (iam.- Two perfect specimens and several odd valves. A very pretty form.

T. Acropagia) scobinata linne. Two fine examples.

T. (Tellinula) culter Hanley. A few brilliantly-coloured examples, 'crimson, white, or yellow.

T. (Tellinula) dispar Conrad.-One specimen.

Macoma æqualis I)eshayes. A few examples near .1\%. suhovatu Sow. W'e fancy the true M. subovatu also occurs, its head-quarters being New Zealand.

\section{BRACHIOPOI)A. \\ FAMIL TERERKATULIDA:}

Terebratella sanguinea (hem).- -Three specimens. 


\section{ADDENIAA.}

Upon again examining the last collection sent over by Mr. Hadfield, we find several species which we regret were not noticed in time to be placed in their proper sequence in the foregoing list. We now append them, and they will serve as a froof, should such be needed, that the resources of these islands are very far from being exhausted, and that any future consignments from this locality would be the means of adding several important, and possibly specifically new additions, to the large number already catalogued.

Rhytida Deplanchesi Gassies.-Several.

R. ouveana Souverbie.-Three specimens.

Planorbis Rossiteri Crosse.-Several.

Conus (Rhizoconus) capitaneus Linné.- One, in very fine condition, with epidermis.

C. (Lithoconus) Gruneri Reeve-One.

Oliva (Strephona) carneola I amarck. Several, showing some variation of banding and colour.

Latirus (Peristernia) Wagneri Ant.-. L. crenulatus Reeve.-One or two.

Ranella (Lampas) Paulucciana Tapp.-Cancfri. ()ne, il good specimen and very distinctive.

Triton verrucosus Reeve- - One specimen.

T. (Lotorium) sinensis Reeve.--Several.

Cypræa aurora Sol. (p. I I2).--Mr. Hadficld, in letter dated July 27, I 894 , gives the following additional information: "Mrs. Hadfield has come upon a rare treasure in the shape of a fine orange Cowrie. It is reported among the natives that the old woman who found it was struck on the forehead by a demon, who asked her why she took the shell, a similar one never having been found in those waters. She died from the effects of the blow, so her good pastor tells me." 
Cerithium nodulosum Bruguière. -One very fine specmenen. Mitra (Pusia) Montrouzieri Souverbie. This little specie's is more commonly known as $\boldsymbol{M}$. tricolor Montr, a name preoccupied by a Mediterranean species (.1/. triollo (smel.).

Engina pulchra Reeve. -One, typical and very heautiful.

Purpura (Thalessa) echinata Blainville. - Two specimens. Pentadactylus (Sistrum) elongatus Blainville cancellatus Quoy.-One good specimen showing the characteristic interstitial pitting.

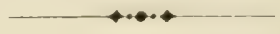

\section{ERRATA.}

Page 88, line $\mathrm{\tau}$ S. - "Plecotrema." Since the former part of this paper was put in type, Mr. F. R. Syke's has puhlished (Prox. Mal. Soc., vol. i., pp. $2+1-299)$ an exhaustive review of the genus Plecotrema $\mathrm{H}$. \& $\Lambda$. Adams. In accordance with the law of priority, the two species hitherto known as $P$. labrellum H. \& A. Adams and $P$. Sonrerliei Montr. must now be termed $P$. striatum Philippi and $P$. bellum $\mathrm{H}$. \& A. Adams respectively.

Page 107, line 19.-For " uricata" read " muricata."

Page ro8, line 25.--For "fig. i 2 " read "fig. 1 3."

Page i r , line 30.-Lior "plate I." read "plate II."

Page Ir 7 , line i I.-Delete "(Pl. III., fig. 27)."

Page i 9 , line 19. - For "0.3" read " 3 ." 


\section{EXPLANATION OF PLATE II.}

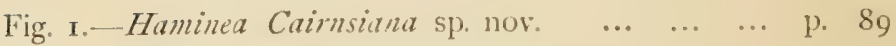

"2.-Terebra (Myurella) nectarea sp. nov. ... ... ", 9I

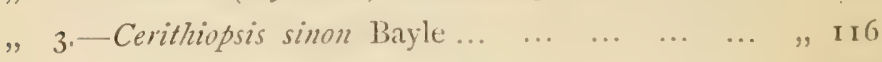

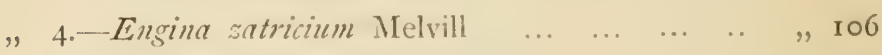

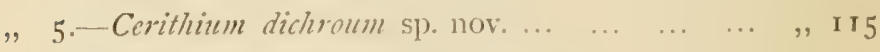

, 6.-Engina mundula sp. nov. $\quad$...

"7,8.-Cypraa Rashieighana Melvill _..

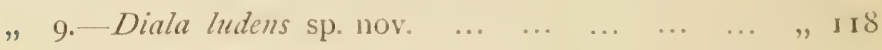

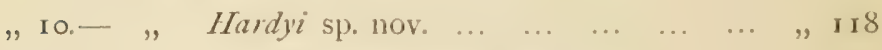

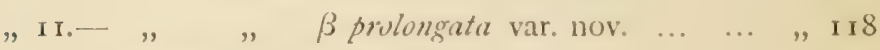

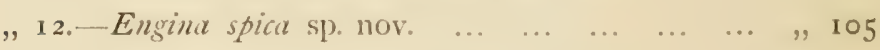

" I 3-Murex (Ocinebra) benedictus sp. nov. ... ... „, 108

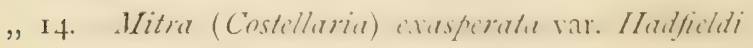

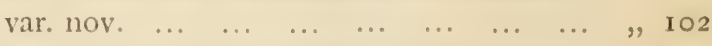

", 15.-Mangilia (Glyphostoma) Alicice sp. nov. ... " 95

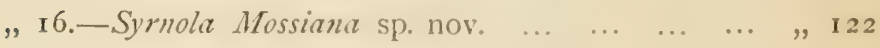



Plate II.

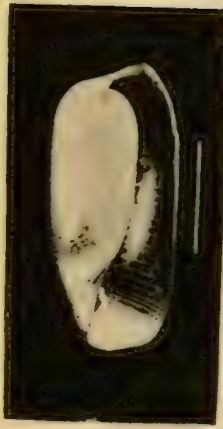

1
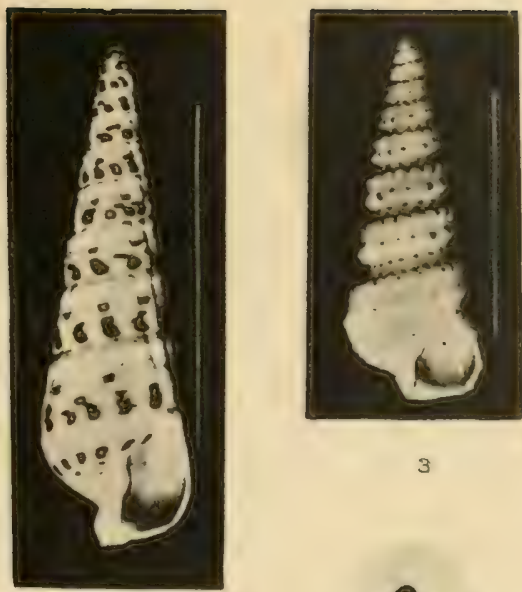

3
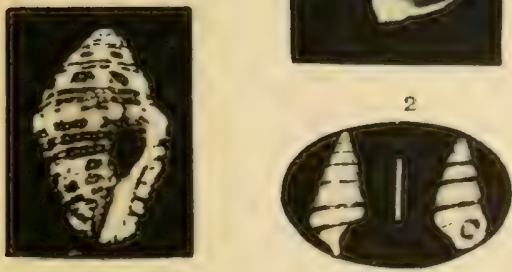

gased I

$\xi$

5

6

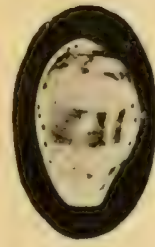

7

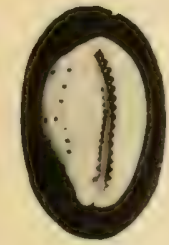

$\varepsilon$

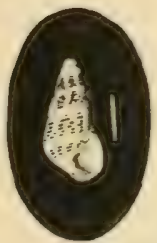

g

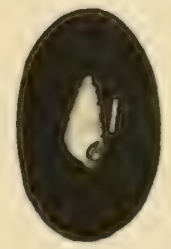

10

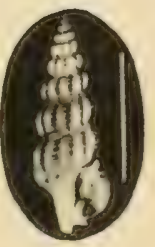

15

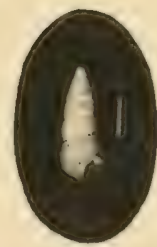

11

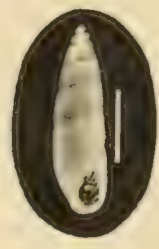

16 



\section{EXPLANATION OF PLATE III.}

Fig. r 7.-Mitra (Volutomitra) honesta sp. nov... $\quad . . \quad$ p. ror

„, I8.-Minolia glaphyrella sp. nov. $\quad \ldots \quad \ldots \quad \ldots \quad, \quad$ I25

" 19.-Mitra (Costellarin?) nitidissima sp. nov. ... ", 102

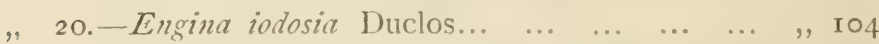

"2 2r.-Mangilia (Glyphostoma) calcicincta sp. nov. " 95

, 22.-Barleeia Chasteri sp. nov. ...

" 23.-Pleurotoma (Drillia) Hadfieldi sp. nov. ... " 94

"24.-Mangilia (Glyphostoma) Emme. sp. nov. ... " 96

" 25.- " " (Daphnella) dulcinea sp. nov. ..., 98

", 26.- " (Glyphostoma) theskela sp. nov. ... " 97

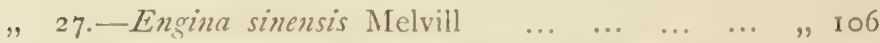

28, 29.-Cyprera dindestina I inné var. Arnffili Jouss. „ I 2

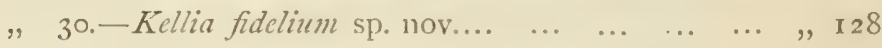

"3 1.-Mangilia (Glyphostoma) cremonilla sp. nor. " $\quad 96$

"32.-Mitra (Chry'same) fulvosulata Melvill ... " го I

"33.-Cerithium armatum var. lifuensis var. nov.... " I 5 
Plate.III .

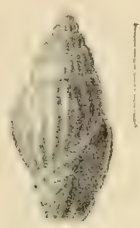

17

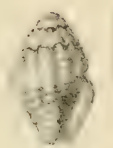

20

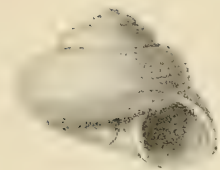

18

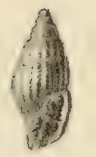

10

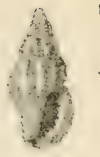

23

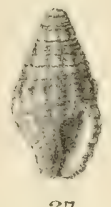

27
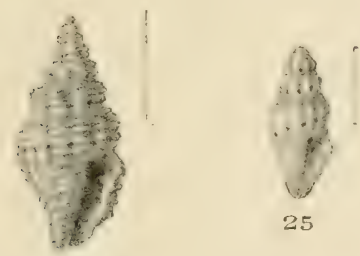

25

24

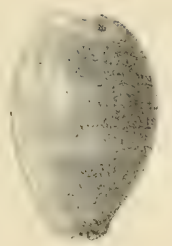

28

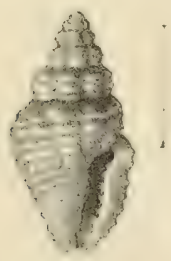

31

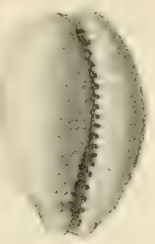

29

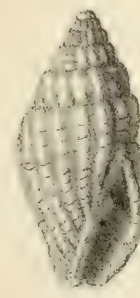

32
26

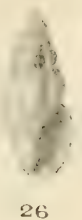

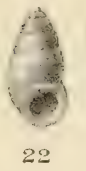

\section{$x^{2}$}

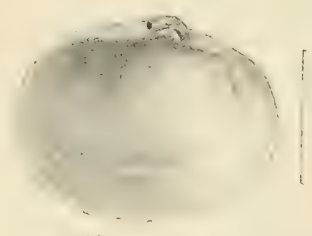

30

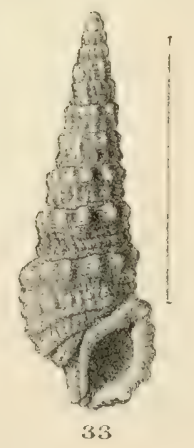

West, Newman imp.

G.M.Woodward del et lith. 



\section{MUSEUM REGULA'TIONS.}

I.- The Museum is open to the public daily, from I I a.m. to 4 p.m., during the months of November to February; II to 5 during March, April, September, October; and I I to 6 from May to August. Admission free and without ticket.

2.- The Museum and Museum Library are further open to persons desirous to make use of them for the purposes of study. The Keeper will issue tickets of admission on suitable recommendation.

3.- Students of the College are admitted to the Museum on any day in the week between the hours of $10 \mathrm{a} . \mathrm{m}$. and 5 p.m. Those whose studies necessitate access to the specimens and the loan, for use in the Museum buildings only, of the books in the Museum Library, may procure Students' tickets from the Keeper, on the recommendation of the Professors or Iecturers in the several departments, such tickets to be valid only for the session in which they were issued.

4.-The Museum is closed on Ash Wednesday, Good Friday, and Christmas Day. 


\title{
MUSEUM HANDBOOKS.
}

The following are ready, and may be had at the Museum or of the Publisher-

\author{
MR. J. E. CORNISH,
}

St. Ann's Square,

MANCHESTER.

General Guide to the Museum (Illustruted) - _ - Price 6d.

Catalogue of the Embryologieal Models _ _ _ Price 15.

Catalogue of the Type Fossils - $-\quad+\quad-\quad$ Price 2s.

Outline Classification of the Animal Kingdom - _ Price $2 \mathrm{~d}$.

Outline Classification of the Vegetable Kingdom - P'ine 2d.

Catalogue of the Library $\quad \ldots \quad \ldots \quad \ldots$ Price 2s. $6 \mathrm{~d}$.

". $\quad$, (bound in cloth and interleared) Priec 5s.

Catalogue of the Hadfield Collection of Shells from the Loyalty Islands (with two plates) _ _ _ 
QL 406

$\mathrm{M} 4$ pt.1
Melvill, James Cosmo Catalogue of the Hadf collection of shells fro Lifu and Uvea

Biological

\& Medical

\section{PLEASE DO NOT REMOVE}

CARDS OR SLIPS FROM THIS POCKE

UNIVERSITY OF TORONTO LIBRARY 
